\title{
Layout Improvement Towards Lean System In Manufacturing Company
}

\author{
A. N. Aizat Ahmad, Md. Fauzi Ahmad, Norhadilah Abdul Hamid, Adnan Bakri, Mustaqqim \\ Abdul Rahim
}

\begin{abstract}
Facility layout arrangement is one of the factors that can give a significant impact on the company's performance. Poor implementation of facilities arrangement can lead to ineffective and inefficient work system which may limit the rate of productivity, poor utilization of resources, high rate of rejection and many more. Thus, this study was conducted in order to solve the problem by proposing several solutions to the company for layout problems. Data collection were done by using several methods such as observation, interviews and measurement. A measuring tool been used in this study by using measuring tape to measure the distance of process flow, size of machines and space between machine to machines. The performance of each alternatives were calculated by comparing the total distance of process flow between actual layout and alternatives layout which were being measured by using measuring tape as a measuring tool for this study. From the evaluation, 1 layout was selected as it provide the highest percent of improvements. Proposed layout is not only has reducing the congestion level of the company but also increase its performance.
\end{abstract}

Keywords: Layout Design, Lean Manufacturing, Process Layout, Facility layout

\section{INTRODUCTION}

Layout design affected a big impact on performance of manufacturing system. Thus the set position of effective layout should be involved in improving the productivity of the plant (Allegri, 1984; [52]). Layout design is basically the arrangement of machines or workstations at production floor to provide smooth movement of resources such as raw materials and workers. An effective layout design is important for good manufacturing of products or delivery of services [13].

However, an optimal layout is normally determined when the production capacity is maximized. The relationship between productivity and effectiveness of the layout can be seen when we compare between the actual quantities of output produced with the main aim of the industry. Facility layout considers final product, available space, facility and

Revised Manuscript Received on September 14, 2019.

A. N. Aizat Ahmad, Department of Production and Operation Management, Faculty of Technology Management and Business, UniversitiTun Hussein Onn Malaysia (UTHM), Malaysia. (Email: aizat@uthm.edu.my)

Md. Fauzi Ahmad, Department of Production and Operation Management, Faculty of Technology Management and Business, UniversitiTun Hussein Onn Malaysia (UTHM), Malaysia.

Norhadilah Abdul Hamid, Department of Production and Operation Management, Faculty of Technology Management and Business, UniversitiTun Hussein Onn Malaysia (UTHM), Malaysia.

Adnan Bakri, Facilities Maintenance Engineering Department, Malaysia

Mustaqqim Abdul Rahim, Department of Civil Engineering, School of Environmental Engineering, Universiti Malaysia Perlis (UniMAP), Malaysia Universiti Kuala Lumpur -Malaysian Institute of Industrial Technology,

convenience of operations, as well as safety of users. Facility layout looks at physical allocation of space for economic activity in the plant. Hence, the facility layout planning aims to design effective workflow to improve the productivity of equipment and workers.

There are several significant problems regarding to the scope of project that exists in the case study where studied company also faced the same problem where their layout was not efficient to the workers. The arrangement of machines and all parts are not in systematic position. Due to this problem this company facing a problems on operation of the system and production. The layout of this company also in poor layout planning where their existing plant layout and the facilities arrangement is basically allocated base on managers experiences and without any proper planning. Besides, it is also improper material flow. The flow of the raw materials and the finishing products are occupying the same path and it disturbing their workers or operators to pass the product to other machines. It also called as long distance material flow.

There is also a problem when the production stop due to fail in testing the product, the trolleys that are placed for the products became stacked on the hallway and this is disturbing their operators to move from one place to another and it also made the production time become longer. Layout is an integral part of a Lean Manufacturing Strategy. Meaningful restructuring requires corresponding physical changes in the layout. Therefore, the best plant layout need to be proposed in order to optimize the material flows and the total travelled distance between departments. Hence, this study aims for 3 main objectives which are: (i) to identify the actual layout and process flow of the company, (ii) to analyze and evaluate the existing layout based on the lean aspects and (iii) to propose the best and effective layout of the company based on the criteria related.

\section{LITERATURE REVIEW}

\subsection{Lean Manufacturing System}

Layout is also a part of improving effectiveness of lean system in company. The aims of lean manufacturing is to expend less inventory, less human effort, less space, and less

time to develop products to become highly responsive to customer demand, while at the same time producing quality products in the most economical and efficient manner [41]. In this research, by improving facility layout design by

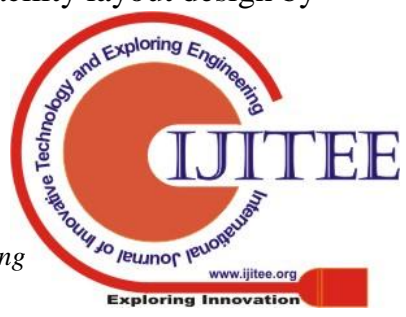




\section{LAYOUT IMPROVEMENT TOWARDS LEAN SYSTEM IN MANUFACTURING COMPANY}

determining how to arrange, locate and distribute the equipment and support services in a manufacturing facility to achieve the effectiveness of lean criteria which are maximization of operational and arrangement flexibility, minimization of overall production time, maximization of factory output in conformance with production schedules, and maximization of turnover of work-in-process.

\subsection{Layout}

Layout design and the flow of materials is significantly affected the performance of manufacturing [50]. These can help to reduce work in process and inventory, increase productivity, reduce streamlines the flow of materials, reduce short production lead time, and reduce non value added activities from the production process of waiting and movement, ultimately fulfill the customers' requirement [18].

\section{RESEARCH METHODOLOGY}

There are many methods that can be used to obtain the necessary data such as interview and questionnaire method. For this study, a suitable method used are the method of interviewing, data collection and observation. Respondents that suitable to be interviewed were identified through their experience in managing the project and engaged in the layout engine at the factory. This work experience is obtained through interviews conducted. Interviews is conducted in a controlled manner.

The interview process is usually carried out at times outside of office hours so that respondents would have more time to be interviewed. All of discussion during the interview were recorded. All the measurement were measured by using measuring tape and measuring wheel in the production area. All the data and information obtained was recorded and all information obtained were analyze in detail to achieve the objectives of the research.

\section{DATA ANALYSIS\& RESULTS}

\subsection{Existing Layout's Analysis}

Basically, there are three main concepts of layouts, namely product layout, process layout, and fixed position layout. The studied company used the product layout. This product layout is based on only 1 item to be produces in particular cycle. However, due to space constraints, the allocation of machinery for the current layout is ineffective within the department. Therefore, the flow of processes and the flow of materials for a particular product is not very smooth. After problems occurred have been identified, flow analysis and activity analysis are conducted and discussed. Figure 4.1 shows that there are three conveyor dispatchers followed by three flow regulator assemblies, bag assembly, and IDS assembly. In addition, there are five filter machines, filter flushes, hood cells, body cells and packing assembly. Their layout also has the space to test IDS to confirm the product quality before moving for the next process.

Referring to Figure 4.1, it represents the form of the existing layout that shows the flow of moving material from one work station to another to produce Kestrel. From the picture it is clear that the material flow principle is violated where the transfer of materials from the process regulatory assembly to body cell are distract the IDS assembly and the congestion situation is created by this movement. The movement of items in this congested area not fully necessary, therefore unnecessary movement should be eliminated or minimized. Due to the direct flow of materials influenced by item arrangement, restructuring and rearrangement of the layout can result in significant increases in the flow of moving material flows.

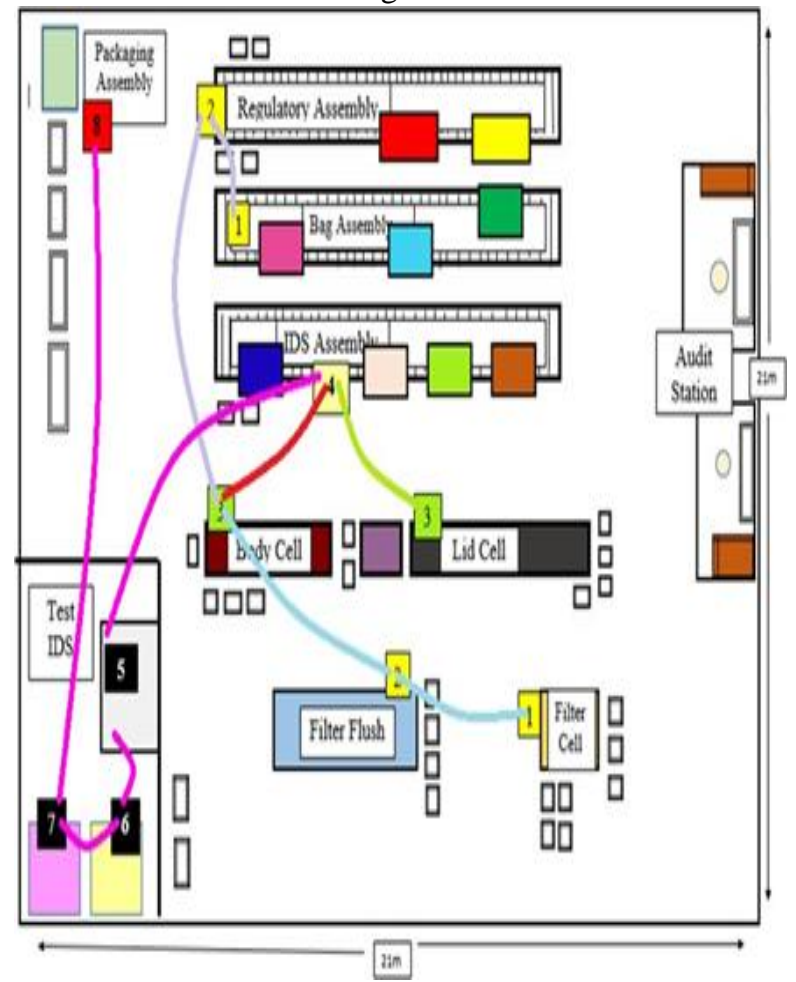

Figure 4.1 Process flow of existing layout of Kestrel Line.

\subsection{Problems in Existing Layout}

Problems in existing arrangements are identified based on the information and data collected from discussions made with supervisors and some employees as well as surveys made on existing arrangements. Among the problems identified are as follows:

a) The position of the machine was irregular and not systematic. This greatly influences the overall operation time and the amount of distance that every employee has to undergo in the routine work.

b) There is still a completely empty production floor space.

c) Material damaged occurs when handling material.

d) The problem occurred when the employee sends the material ahead and the material requires a large space to store. This created a bottleneck problem in the processing part and cause the workplace to be congested. 


\subsubsection{Alternative Layout based on Centralized Location}

Based on Figure 4.3.1, there is a slightly changes made that followed the appropriate criteria which is by centralizing the machine of body cell process become nearer with other machines in order to minimize flow and maximize directed flow path. The directed flow path of this layout are still the same with the process flow of the existing layout but only changed the position of body cell machine to the center to all machines. This will make the operator become easier to deliver material to one process to another process and also the production time were reduced once the distance between the process are close to each other. This layout also eliminated causes of delay problems such as shortage of space, long distance movements of materials, spoiled work and thus contributes to the speedy execution of orders.

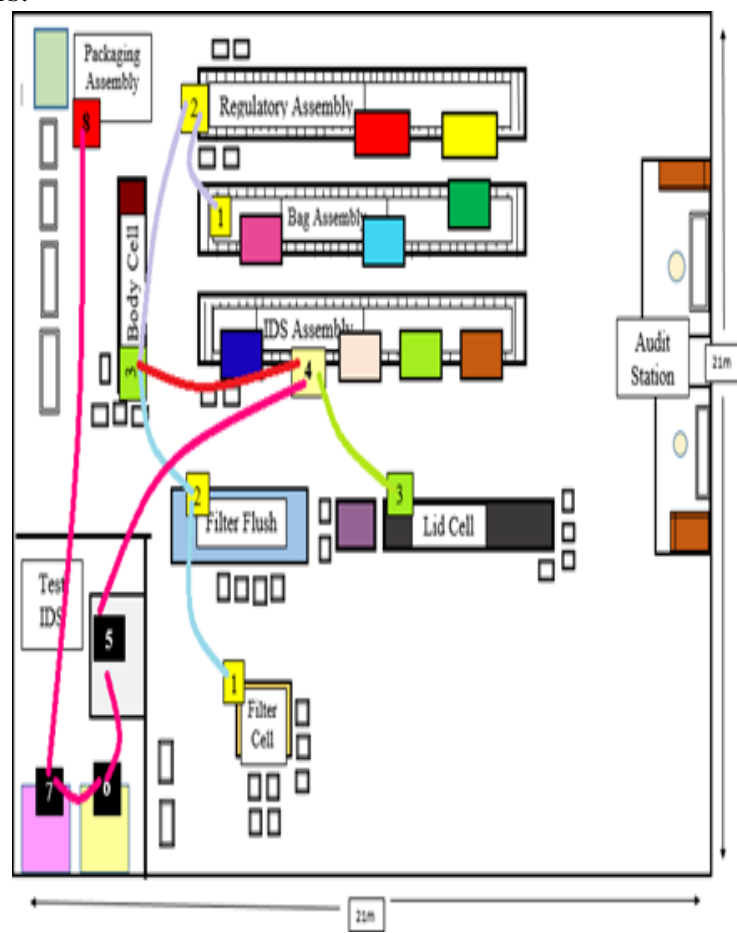

Figure 4.3.1: Alternative layout based on centralized location

\subsubsection{Alternative Layout based on Material Handling}

Figure 4.3.2 shows that second improvement layout that can be proposed to the studied company based on material handling criteria. This layout shows the changes in the position of body cell machine to the right side of the layout and also the changes in direction path flow of process to reverse directed flow but the process flow of Kestrel still the same and do not effect overall process. This is because of the problem that always happened in the company where their hallway between machine to machine are too narrow for their cart that almost all large size to go through the pathway in delivery the product for next process. Although the process is reverse it can facilitates material handling. This is also reduced the production time without congestion occurred. The changes of filter machines position also can be made where machine filter flush nearer to the body cell machine.

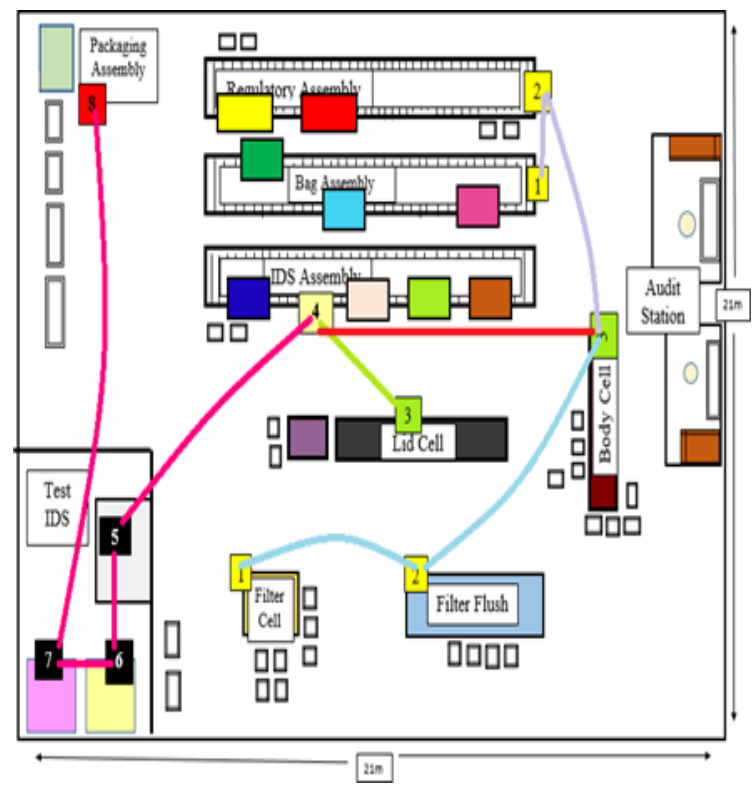

Figure 4.3.2: Alternative layout based on Material Handling

4.3.3 Alternative Layout Based on Smooth Movement and Space Utilization

Figure 4.3.3 show that the changes position of all machines and conveyors which can accommodate and fully use the empty space in their plant layout. This is the best improvement that can be made by the company in order to have an efficient layout. Although this is the best layout it can be their last option because by changing fixed machines like conveyors will involve high cost to redesign the layout. Even the company also need to shut down and it will take almost around 3 weeks. But this improvement is the most effective layout that can be made with only one piece flow of materials and there is no congestion while handling the materials and also wide flexibility in getting works done. Possible assigned jobs to any machines in the same class available at the time.

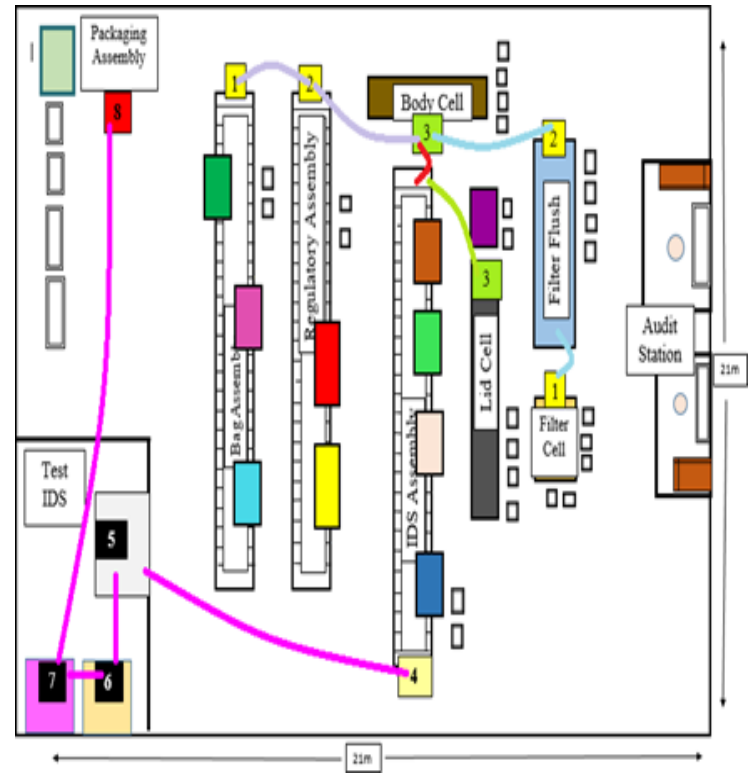

Figure 4.3.3: Alternative layout based on Smooth Movement and Space utilization 


\section{LAYOUT IMPROVEMENT TOWARDS LEAN SYSTEM IN MANUFACTURING COMPANY}

\subsection{Distance Movement Comparison with Existing} Layout

Table 4.4 showed that the distance movement from one process to another process compared with the distance movement of the existing layout. All the measurement were measured by using measuring tape and measuring wheel. By using measuring tape it remained stiff and straight when extended. It can be seen that the total for alternative layout based on smooth movement and space utilization which is 39.59 meter was the best improvement can be made compared to the existing layout which is the distance took 60.77 meter to deliver the product from one station to final station. By reducing the distance between processes, the production become more efficient and effective.

Table 4.4: Distance movement comparison with existing layout

\begin{tabular}{|l|l|l|l|l|}
\hline $\begin{array}{l}\text { Distance } \\
\text { Moveme } \\
\text { nt } \\
\text { (material } \\
\text { ) }\end{array}$ & $\begin{array}{l}\text { Existin } \\
\text { g } \\
\text { Layou } \\
\text { t }\end{array}$ & $\begin{array}{l}\text { Alternativ } \\
\text { e 1 } \\
\text { (centralize } \\
\text { d) }\end{array}$ & $\begin{array}{l}\text { Alternati } \\
\text { ve 2 } \\
\text { (material } \\
\text { handling) }\end{array}$ & $\begin{array}{l}\text { Alternati } \\
\text { ve 3 } \\
\text { (smooth } \\
\text { movemen } \\
\text { t and } \\
\text { space } \\
\text { utilizatio } \\
\text { n) }\end{array}$ \\
\hline TOTAL & $\begin{array}{l}60.77 \\
\mathrm{~m}\end{array}$ & $\mathbf{5 3 . 1 4 m}$ & $59.75 \mathrm{~m}$ & $\mathbf{3 9 . 5 9 m}$ \\
\hline
\end{tabular}

4.5 Alternative Layout 1 (centralized location) VS Existing Layout

Figure 4.5.1 shown bar chart as the differences between the total distance of movement and distance movement of existing layout. Just by looking at how tall the bars are, we can immediately see that the reduction distance for alternative layout 1 is more that existing layout which the difference $7.63 \mathrm{~m}$ and with improvement $(12.56 \%)$.

Reduction Distance: $60.77 \mathrm{~m}-53.14 \mathrm{~m}=7.63 \mathrm{~m}$

Improvement Percentage: $12.56 \%$

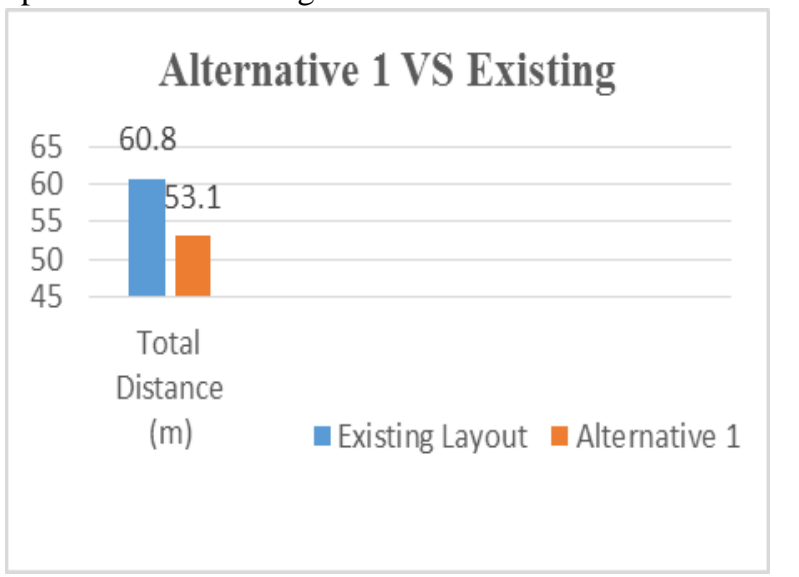

Figure 4.5.1: Alternative Layout 1 (centralized location) VS Existing Layout

4.6 Alternative Layout 2 (material handling) VS Existing Layout

According to figure 4.6.1 shown that the changes of distance movement of alternative layout 2 (material handling) with the existing distance movement of the company's layout which is the reduction distance $1.02 \mathrm{~m}$ and the improvement $(1.68 \%)$ can be made to improve their layout.

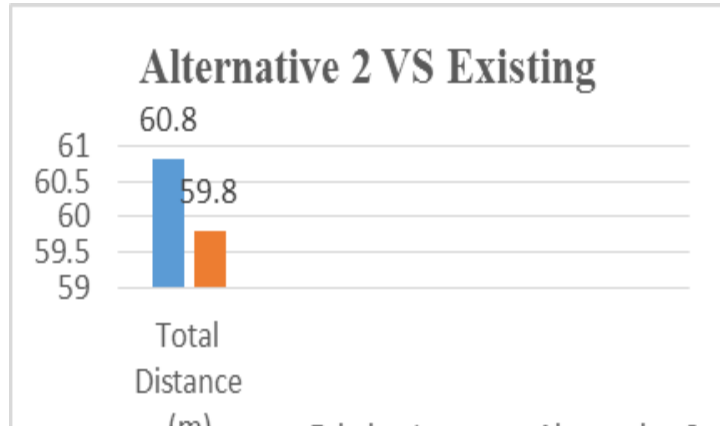

(m) Existing Layout $\square$ Alternative 2

\section{Figure 4.6.1: Alternative Layout 2 (material handling) VS Existing Layout}

Reduction Distance: $60.77 \mathrm{~m}-59.75 \mathrm{~m}=1.02 \mathrm{~m}$

Improvement Percentage: $1.68 \%$

4.7 Alternative Layout 3 (smooth movement and space utilization) VS Existing Layout

Based on the figure 4.7.1 shown that the difference of distance movement of product for alternative layout 3 and with the existing layout. The data showed there was a big difference of distance with the existing layout which is $21.18 \mathrm{~m}$ and $(34.86 \%)$ improvement can be made through this alternative. This is the best option for the company to re-build or re-design their layout for better performance.

\section{Alternative 3 VS Existing}

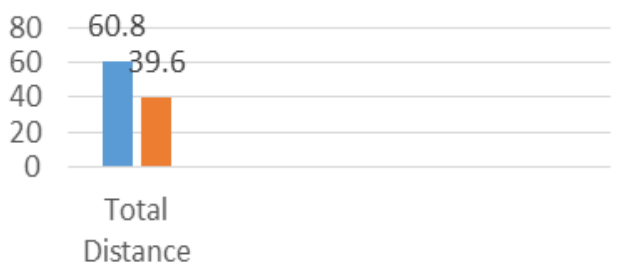

(m)

Existing Layout $\quad$ Alternative 3

Figure 4.7.1 Alternative Layout 3 (smooth movement and space utilization) VS Existing Layout

Reduction Distance: $60.77 \mathrm{~m}-39.59 \mathrm{~m}=21.18 \mathrm{~m}$

Improvement Percentage: $34.86 \%$

From the result, company have decided to choose alternative 3 as a new layout to be implemented in production area. Using this new layout will help the company to improve their operation, increase their conveyor efficiency and will help the production area become smooth and one piece flow production system. Hence, this study assist the company to improve the overall value. 


\section{CONCLUSION}

The objectives of this project are accomplished due to the most effective layout have been chosen. The other option may be refine and relook to capture effective layout of production process. To tackle the problem of ineffective layout arrangement, two methods have been used to design and construct an alternative layout for the studied company. The method used is through relocating materials and machines measured by using measuring tape and measuring wheel. The alternative is then decided based on the comparison between the layout and the existing layout. The best layout is chosen based on the results obtained in the comparison table.

During this study, some of the issues considered in the existing layout have been identified. Therefore, in order to face the problem of the layout described, some procedures have been taken for the start of preparation in alternative layout planning. To produce an effective layout alternative, some layout criteria are being considered. Criteria defined as centralizer, the movement of material handling and layout flexibility. Among the three layout options, one of which has been selected and defined as an effective layout in performing capabilities or functions consciously towards the overall flow of production. From the assessment, alternate layout based on centralized location has been chosen and the most appropriate comparing other alternatives.

\section{REFERENCES}

1. Ahmad A.N.A, Lee TC, Ramlan R., Ahmad M.F. (2017) Value Stream Mapping to Improve Workplace to support Lean Environment, 8th International Conference on Mechanical and Manufacturing Engineering, MATEC Web of Conferences 135, 00032 (2017)

2. Andersson, R., Eriksson, H. and Torstensson, H. (2006), Similarities and differences between

3. TQM, six sigma and lean, The TQM Magazine.

4. Apple, J. M. (1977), Plant layout and Material Handling, New York: John Wiley \& Sons Inc.

5. Askin, R.G., Lundgren, N.H. and Ciarallo, F. (1996). A material flow based evaluation of layout alternatives for agile manufacturing. Material Handling Institute, BraunBrumfield Inc

6. Balakrishnan, J. and Cheng, C.H. (1998), Dynamic layout algorithms, a state of the art survey", Omega,

7. Behrouzi, F. and Wong, K.Y. (2011), Lean performance evaluation of manufacturing systems, Procedia Computer Science.

8. Benjaafar, S. and Sheikhzadeh, M. (2000). Design of flexible plant layouts. IIE Transactions.

9. Braglia, M. (1996). Optimization of a simulatedannealing-based heuristic for single row machine layout problem by genetic algorithm. International Transactions in Operational Research, 3(1), 37-49.

10. Bowen, D. and Youngdahl, W. (1998), Lean service in defense of a production-line approach. International Journal of Service Industrial Management.

11. Bozer, Y. A., Meller, R. D., \&Erlebacher, S. J. (1994). An improvement-type layout algorithm for single and multiple floor facilities. Management Science, 40(7), 918-932

12. Chwif, L., Pereira Barretto, M. R., \&Moscato, L. A (1998). A solution to the facility layout problem using simulated annealing. Computers in Industry, 36(1-2), $125-132$
13. Drira, A., Pierreval, H. and Hajri-Gabouj, S. (2007) 'Facility layout problems: a survey', Annual Reviews in Control.

14. Dilworth, J. B. (1996). Operation management. McGraw Hill.

15. Djellab, H., \&Gourgand, A. (2001). A new heuristic procedure for the single row facility layout problem. International Journal of Computer Integrated Manufacturing.

16. Francis, Richard L. \& White, John A (1974). Facility Layout and Design, Prentice-Hall Inc.

17. Francis, R. L., McGinnis, Jr., L. F. and White, J. A. (1992). Facility Layout and Location: An Analytical Approach. (2nd ed.). Englewood Cliffs, N. J.: Prentice Hall.

18. H. Kaebernick, M. Bazargan-Lari, and G. Arndt, (1996). An Integrated Approach to the Design of Cellular Manufacturing. CIRP Annals - Manufacturing Technology

19. Hamann, T., \&Vernadat, F. (1992). The intra cell layout problem in automated manufacturing system. 8th international Conference on $\mathrm{CAD} / \mathrm{CAM}$, robotics and factory of the future (CARs \& FOF 92).

20. Hassan, M. M. D. (1994). Machine layout problem in modern manufacturing facilities.

a. International Journal of Production Research, 32(11), 2559- 2584.

21. Hassan, M. M. D., Hogg, G. L., \& Smith, D. R. (1986). SHAPE: A construction algorithm for area placement evaluation. International Journal of Production Research,

22. Heragu, S.S. (1997), Facilities Design, PWS-Kent Publishing Co., Boston, MA

23. Heizer, J. and Render, B. (2011). Operations Management. (10th ed.). Edinburgh Gate, England: Pearson Education Limited

24. Huang, H. and Irani, S.A. (1999). Design of facility layouts using layout modules: A numerical clustering approach. Proceedings of the 8th Industrial Engineering Research Conference, Phoenix.

25. Irani, S.A. and Huang, H. (1998). Hybrid cellular layouts. White Paper, Department of Industrial, Welding and Systems Engineering, Ohio State University, Columbus, $\mathrm{OH}$

26. Irani, S.A. and Huang, H. (2000). Custom design of facility layouts for multi-product facilities using layout modules. IEEE Transactions on Robotics and Automation

27. Johnson, R. V. (1982). SPACECRAFT for multi-floor layout planning. Management

a. Sciences, 28(4), 407-417.

28. Kochhar, J. S., \&Heragu, S. S. (1998). MULTI-HOPE: A tool for multiple floor layout problems. International Journal of Production Research, 36(12), 3421-3435

29. Kochhar, J.S. and Heragu, S.S. (1999). Facility layout design in a changing environment. International Journal of Production Research

30. Konz, Stephen (1985). Facility Design. John Wiley \& Sons, Inc.

31. Kim, C. B., Kim, S. S., \& Bobbie, L. F. (1996) Assignment problems in single row and double-row machine layouts during slow and peak periods. Computers \& Industrial Engineering, 30(3), 411-422.

32. Kim, J. G., \& Kim, Y. D. (2000). Layout planning for facilities with fixed shapes and input and output points. International Journal of Production Research. 


\section{LAYOUT IMPROVEMENT TOWARDS LEAN SYSTEM IN MANUFACTURING COMPANY}

33. Kusiak, A. and Heragu, S.S. (1987), The facility layout problem, European Journal of Operational Research

34. Lee, K. Y., Roh, M. I., \&Jeong, H. S. (2005). An improved genetic algorithm for multifloor facility layout problems having inner structure walls and passages. Computers \& Operations Research, 32(4), 879-899.

35. Matsuzaki, K., Takashi, I., \&Yoshimoto,K. (1999). Heuristic algorithm to solve the multifloor layout problem with the consideration of elevator utilization. Computers \& Industrial Engineering, 36(2), 487-502.

36. Meller, R. and Gau, K.Y. (1996), The facility layout problem, recent and emerging trends and perspective, Journal of Manufacturing Systems

37. Meller, R. D., Narayanan, V., \& Vance, P. H. (1999). Optimal facility layout design.

a. Operations Research Letters, 23(3-5), 117-127.

38. Meller, R.D. (2000). Multi-channel manufacturing. White Paper, Department of Industrial and Systems E ngineering, Auburn University, Auburn, AL

39. Meyers, F.E. (1993), Plant Layout and Material Handling, New Jersey: Regents/Prentice Hall

40. Moore, J.M. (1962), Plant Layout and Design, New York: Macmillan Publishing Co.

41. Motwani, J. (2003), A business process change framework for examining lean manufacturing: a case study, Industrial Management and Data Systems.

42. Ohno, T. (1988), The Toyota Production System: Beyond Large Scale Production, Productivity Press, Portland, OR.

43. Patsiatzis, D. I., \&Papageorgiou, L. G. (2002). Optimal multi-floor process plant layout.

Computers and Chemical Engineering, 26(4-5), 575-583

44. Phillips, E.J. (1997). Manufacturing Plant Layout, Fundamentals and Fine Points of Optimum Facility Design, Dearborn, MI: Society of Manufacturing Engineers

45. Potts, C. N., \& Whitehead, J. D. (2001). Workload balancing and loop layout in the design of a flexible manufacturing system. European Journal of Operational Research, 129(2), 326-336.

46. Russell, R. S. and Taylor III, B. W. (2000) Operation Management, Multimedia Version (3rd Edition), Prentice Hall, United States of America.

47. Salvendy, Gavriel (1982). Handbook of Industrial Engineering, New York: John Wiley,

48. Sheth, V. S. (1995). Facilities Planning and Materials Handling, New York: Marcel Dekker Inc.

49. Taj, S. (2007), Lean manufacturing performance in China: assessment of 65 manufacturing plants, Journal of Manufacturing Technology Management.

50. T. Yang and C. Kuo (2003). A hierarchical AHP/DEA methodology for the facilities layout design problem, European Journal of Operational Research.

51. Tompkins, J.A. (1984), Facilities Planning, New York; John Wiley \& Sons Inc.

52. Tompkins, J. A., White, J. A., Bozer, Y. A. Frazelle, E. H., Tanchoco, J. M. A. and Trevino, J. (1996). Facilities Planning (2nd Edition), John Wiley \& Sons Inc.

53. Tompkins, J. A., White, J. A., Bozer, Y. A. and Tanchoco, J. M. A. (2003).

a. Facilities Planning. 3th edition. USA: John Wiley \& Sons. Inc

54. Yang, M.G., Hong, P. and Modi, S.B. (2011), Impact of lean manufacturing and environmental management on business performance, an empirical study of manufacturing firms.

55. Yang, T., Peters, B. A., \&Tu, M. (2005). Layout design for flexible manufacturing systems considering singleloop directional flow patterns. European Journal of Operational Research, 164(2), 440-455.

\section{AUTHORS PROFILE}

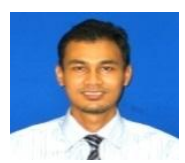

Ahmad NurAizat Ahmad currently works at the Department of Production and Operations, UniversitiTun Hussein Onn Malaysia. His research interest includes Manufacturing Engineering and Industrial Engineering.

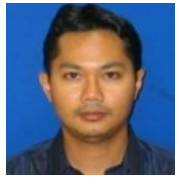

MdFauzi Bin Ahmad is working as Assistant Professor at Faculty of Technology Management and Business, UniversitiTun Hussein Onn Malaysia. His research interest includes Quality Control (QC), Total Quality Management (TQM), Lean Production, Six Sigma, Value Engneering (VE), Visual Management (5S, Kanban), Structural Equation Modelling (SEM) AMOS, PLS , Quality Management System (ISO 9001 and ISO 14001), Statistic Process Control (SPC), Quality Control Circle (QCC) and New Product Development.

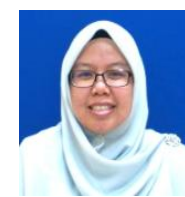

Norhadilah Abdul Hamid is working as lecturer at Faculty of Technology Management and Business, UniversitiTun Hussein Onn Malaysia. Her major research interest is Technology Commercialisation.

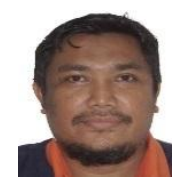

Adnan Bakri is a senior lecturer at Malaysian Institute of Industrial Technology, Universiti Kuala Lumpur. His area of expertise include Maintenance Management, Quality \& Productivity Improvement Via Total Productive Maintenance (TPM), Occupational Safety, Health And Environmental Management (OSHEM) and Autonomous Maintenance (AM) In Manufacturing Industry.

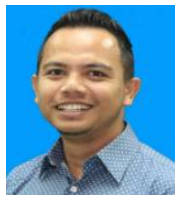

Mustaqqim Abdul Rahim is working as lecturer at Department of Civil Engineering School of Environmental Engineering, Universiti Malaysia Perlis Arau Malaysia. 